\title{
Direct Effects of Nerve Growth Factor- $\beta$, Purified From Bull Seminal Plasma,on Steroidogenesis and Angiogenic Markers of Thebovine Pre-ovulatory Follicle
}

\section{Jamie L. Stewart}

Virginia Polytechnic Institute and State University

Liying Gao

University of Illinois at Urbana-Champaign

Jodi A. Flaws

University of Illinois at Urbana-Champaign

Vitor R.G. Mercadante

Virginia Polytechnic Institute and State University

Nicholas W. Dias

Virginia Polytechnic Institute and State University

Igor F. Canisso

University of Illinois at Urbana-Champaign

Fabio Lima ( $\nabla$ falima@ucdavis.edu )

University of California Davis https://orcid.org/0000-0001-8377-6469

\section{Short report}

Keywords: Angiogenesis, NGF, pre-ovulatory follicle, ruminants, steroidogenesis

Posted Date: July 27th, 2020

DOI: https://doi.org/10.21203/rs.3.rs-48525/v1

License: (c) (i) This work is licensed under a Creative Commons Attribution 4.0 International License. Read Full License 


\section{Abstract}

Nerve growth factor- $\beta$ (NGF) is critical for ovulation in the mammalian ovary and is luteotrophic when administered systemically to camelids and cattle. This study aimed to assess the direct effects of purified bovine NGF on steroidogenesis and angiogenic markers in the bovine pre-ovulatory follicle. A chort of Holstein heifers were synchronized with a standard protocol and heifers with the preovulatory follicle ( $\geq 12 \mathrm{~mm}$ ) had an the ovary containing the dominant follicle removed via colpotomy. Preovulatory follicles were dissected in 24 pieces containing theca and granulosa cells that were randomly allocated to receive either cultured in media supplemented with purified bovine NGF $(100 \mathrm{ng} / \mathrm{mL})$ or untreated (control) for $72 \mathrm{~h}$. The supernatant media was harvested for determination of progesterone, testosterone, and estradiol, whereas explants were used for mRNA analyses for steroidogenesis and angiogenic markers. Treatment of follicle tissue with NGF upregulated gene expression of steroidogenic enzyme HDS17B $(P=0.04)$ and increased testosterone production $(P<0.01)$. However, NGF treatment did not alter production of progesterone $(P=0.81$ ) or estradiol $(P=0.14)$. Consistently, gene expression of steroidogenic enzymes responsible for producing these hormones ( STAR , CYP11A1, HSD3B , CYP17A1, CYP19A1) were unaffected by NGF treatment $(P \geq 0.31)$. Treatment with NGF downregulated gene expression of the angiogenic enzyme FGF2 $(P=0.02)$ but did not alter PGES ( $P=0.63)$, VEGFA ( $P$ $=0.44)$, and ESR1 $(P=0.77)$. Collectively, these results demonstrate that NGF from seminal plasma may interact directly with the bovine pre-ovulatory follicle to alter downstream steroidogenesis and luteal development.

\section{Background}

Nerve growth factor- $\beta$ (NGF) is a member of the neurotrophin family that has a critical role in mammalian follicle development and ovulation $(1,2)$. Expression of NGF has been localized to ovarian granulosa cells prior to the formation of the first primordial follicles in neonatal mice (2) and rats (3) and is involved in initiating folliculogenesis (4). Though present during late fetal development, expression of NGF and its receptor, TrkA, in the ovary decreases postnatally between 24 and $48 \mathrm{~h}$ after birth and remains low until puberty in rats (3). At the time of the first pre-ovulatory luteinizing hormone (LH) surge, transient activation of NGF/TrkA occurs and is integral to the process of follicular cytodifferentiation proceeding the first ovulation (1). In bovine theca cells, NGF induced prostaglandin $E_{2}$ (PGE) synthesis (5), which facilitates follicular rupture at ovulation (6). Additionally, NGF/TrkA signaling in theca cells contributes to the loss of gap junctions within the follicular wall that precedes ovulation (7). The presence of both LH and follicle-stimulating hormone (FSH) in vitro were necessary to stimulate NGF secretion from medium to large follicles in ewes, suggesting a synergistic role with gonadotropins during the pre-ovulatory cascade (8). Consistently, follicular NGF concentrations increased following the gonadotropin peaks in ewes, and in vitro treatment with NGF induced marked cumulus expansion and progressive cumulusoocyte uncoupling (9), which functions to reinitiate meiotic progression of the oocyte at ovulation.

Our understanding of the role of NGF in promoting mammalian ovulation became even more complex when it was identified as the ovulation-inducing factor in camelid seminal plasma $(10,11)$. Though the 
ability of the ovary to produce NGF in spontaneously ovulating species is well documented, few studies have evaluated whether the introduction of NGF from seminal plasma at time of breeding may have a role within the bovine hypothalamic-pituitary-ovarian axis (12-15). In camelids, intrauterine absorption of seminal plasma NGF into systemic circulation occurs within 15 min of copulation, after which it stimulates the preovulatory LH peak from the anterior pituitary gland and exerts a dose-dependent luteotropic effect on the developing corpus luteum (CL) (16). Studies have shown that NGF retains its luteotropic properties when administered systemically to cattle (12-14). While the luteotropic effect in camelids is attributed to the prolonged LH secretion from the pituitary, in cattle, there is evidence that NGF from the seminal plasma may act directly on the ovary (5).

Similar to camelids, bull seminal plasma contains NGF, which is concentrated into the sperm-rich fraction of the ejaculate, facilitating its transit into the cow reproductive tract (17). The bovine uterus maintains a local countercurrent exchange between the uterine venous drainage and the ovarian artery that allows for direct transport of prostaglandin $F_{2 a}\left(P F_{2 a}\right)$ from the uterus to the ovary during luteolysis $(18,19)$. This anatomical mechanism could also provide a potential route for NGF to travel to and interact directly with the ovary (20). A previous study demonstrated that treating bovine theca cells with recombinant NGF in vitro resulted in increased androstenedione and progesterone release, PGE production, and theca cell proliferation when compared to hCG-treated controls (5). However, the signaling cascade within the ovary involves a complex interaction between the theca and granulosa cells, which has yet to be elucidated. This study aimed to assess the direct effects of NGF, purified from bull seminal plasma, on steroidogenesis and angiogenic markers in theca and granulosa cells of the bovine pre-ovulatory follicle. We hypothesize that NGF administration would stimulate steroidogenesis and angiogenic markers in thecal and granulosa cells from the bovine pre-ovulatory follicle.

\section{Materials And Methods}

\section{Heifer synchronization and ovariectomy}

A cohort of cyclic heifers (presence of corpus luteum $>16 \mathrm{~mm}$ and pre-ovualtory follicle $>12 \mathrm{~mm}$ ) had their estrous cycle synchronized. The heifers received an intravaginal progesterone-releasing device (1.38 g progesterone; Eazi-Breed CIDR, Zoetis, Parsippany-Troy Hills, NJ, USA) and an injection of GnRH agonist (100 $\mu$ g Factrel ${ }^{\circledR}$, Zoetis, Parsippany-Troy Hills, NJ, USA) intramuscularly. The intravaginal device was removed 5 days later, and heifers were given $\mathrm{PGF}_{2 \mathrm{a}}$ analog $(25 \mathrm{mg}$ dinoprost tromethamine, Lutalyse, Zoetis, Parsippany-Troy Hills, NJ, USA) intramuscularly at the time of the intravaginal device removal and again $24 \mathrm{~h}$ later. Heifers were examined daily by transrectal ultrasonography to assess response to the synchronization program. Heifers that initiate follicle development and ovulate after the first $\mathrm{GnRH}$ treatment and had luteolysis after $\mathrm{PGF}_{2 a}$ were eligible to have an ovariectomy. The procedure to remove the ovaries was performed at $48 \mathrm{~h}$ after the second $\mathrm{PGF}_{2 \mathrm{a}}$ injection when the dominant follicles reached at least $12 \mathrm{~mm}$ in diameter. Ovariectomy was performed via colpotomy in the standing position under sedation with $15 \mathrm{mg}$ intramuscular xylazine (AnaSed® Injection, Lloyd, Inc., Shenandoah, 
IA, USA) and caudal epidural anesthesia with $5 \mathrm{~mL}$ of $2 \%(\mathrm{w} / \mathrm{v})$ lidocaine $\mathrm{HCl}$ (VetOne ${ }^{\circledR}$, Boise, Idaho, USA) performed. Heifers were treated pre-operatively with ceftiofur crystalline free acid $(6.6 \mathrm{mg} / \mathrm{kg}$; Excede ${ }^{\circledR}$, Zoetis, Parsippany-Troy Hills, NJ, USA) injected subcutaneously in the base of the ear to prevent infection. Flunixin meglumine (2.2 mg/kg; Norbrook® Inc., Overland Park, KS, USA) was administered intravenously daily for two to control inflammation and pain. An incision was made in the dorsolateral aspect of the vaginal fornix, and the peritoneum was manually punctured after blunt dissection through the adventitia. The mesovarium was manually compressed, and the ovary containing the dominant follicle was removed using a chain écraseur. Ovaries were placed in ice-cold phosphate-buffered saline solution containing $2 \%$ antibiotic-antimycotic mixture $(25 \mu \mathrm{g} / \mathrm{mL}$ amphotericin $\mathrm{B}, 10,000 \mathrm{units} / \mathrm{mL}$ penicillin, $10,000 \mu \mathrm{g} / \mathrm{mL}$ streptomycin; Gibco, Gaithersburg, MD, USA) for transport to the laboratory.

\section{Isolation of follicular wall cells and treatment allocation}

The pre-ovulatory follicle was identified and dissected away from each ovary for use in the tissue culture system (Fig. 1). Follicular fluid was aspirated to facilitate further dissection and frozen at $-80^{\circ} \mathrm{C}$. The follicles were dissected into quarters, and the theca interna with adherent granulosa cells was peeled from the theca externa and surrounding stromal tissue. The remaining follicle wall preparations (theca interna and granulosa cells) were cut into 26 pieces (average weight: $5.3 \pm 0.7 \mathrm{mg}$ ), 24 of which were transferred to a costar 24-well plate (1 piece/well; Cambridge, MA, USA) for tissue culture, as previously described $(21,22)$. The remainder of the tissue was flash-frozen in liquid nitrogen and maintained at $80^{\circ} \mathrm{C}$ until mRNA extraction.

The dissected 24 follicle wall pieces containing theca and granulosa cells were randomly allocated to receive a culture medium that was either supplemented with purified bovine NGF $(100 \mathrm{ng} / \mathrm{mL}, \mathrm{n}=12)$ or left untreated (control, $n=12$ ). The single plate was incubated at $37^{\circ} \mathrm{C}$ in a humidified incubator gassed with $5 \% \mathrm{CO}_{2}: 95 \%$ air for $72 \mathrm{~h}$. The NGF used was purified from bovine seminal plasma, as described previously (13). The follicle wall pieces were cultured in $0.5 \mathrm{~mL}$ of medium consisting of Eagle's MEM (Invitrogen, Carlsbad, CA, USA) supplemented with 1\% L-glutamine (Gibco, Gaithersburg, MD, USA), 1\% nonessential amino acids (Sigma-Aldrich, St. Louis, MO, USA), 1\% penicillin-streptomycin (Sigma-Aldrich), $1 \%$ ITS (10 ng/ml insulin, $5.5 \mathrm{ng} / \mathrm{ml}$ transferrin, $5.5 \mathrm{ng} / \mathrm{ml}$ selenium, Sigma-Aldrich), 10\% fetal bovine serum (FBS, Atlanta Biologicals, Lawrenceville, GA), $40 \mathrm{ng} / \mathrm{mL}$ cortisol (Sigma-Aldrich), $4 \mathrm{ng} / \mathrm{mL}$ human recombinant LH (Dr. A. F. Parlow, National Hormone and Peptide Program, Harbor- UCLA Medical Center, Torrance, CA, USA), and $4 \mathrm{ng} / \mathrm{mL}$ human recombinant FSH (Dr. A. F. Parlow, National Hormone and Peptide Program).

\section{Hormone assays}

The aliquots $(0.5 \mathrm{~mL})$ of culture medium at $3,6,12,24,48$, and $72 \mathrm{~h}$ of culture were collected and preserved at $-20^{\circ} \mathrm{C}$ for subsequent steroid assays. Progesterone, testosterone, and estradiol- $17 \beta$ secretions by granulosa and theca cells into the culture media were assessed using immunoassays (Immulite 2000 XPi platform; Siemens Medical Solutions, Malvern, PA, USA, Inc.). Total hormone production for each well was calculated by multiplying the measured concentration by the volume of 
media $(0.5 \mathrm{~mL})$ and then dividing by tissue weight $(\mathrm{mg})$. Intra-assay coefficient of variations were $4.0 \%$ (testosterone), 2.4\% (progesterone), and 3.1\% (estradiol-17 $\beta$ ). Inter-assay coefficient of variations were $12 \%$ (testosterone), 19\% (progesterone), and 15\% (estradiol-17 $\beta$ ). The progesterone assay had a detection range of 0.2 to $40 \mathrm{ng} / \mathrm{mL}$ and a sensitivity of $0.1 \mathrm{ng} / \mathrm{mL}$. The testosterone assay had a detection range of 20 to $1600 \mathrm{ng} / \mathrm{mL}$ and a sensitivity of $15 \mathrm{ng} / \mathrm{dL}$. The estradiol-17 $\beta$ assay had a detection range of 20$2000 \mathrm{pg} / \mathrm{mL}$ and a sensitivity of $15 \mathrm{pg} / \mathrm{mL}$.

\section{Quantitative real-time PCR analyses}

At the completion of the 72-h culture period, follicle wall pieces were weighed and flash-frozen and kept at $-80^{\circ} \mathrm{C}$ until RNA extraction. Follicular tissue mRNA expression was determined for $\mathrm{LH} /$ choriogonadotropin receptor ( $L H C G R)$, FSH receptor (FSHR), PGE synthase (PGES), vascular endothelial growth factor A isoform 121 (VEGFA121), fibroblast growth factor 2 (FGF2), estrogen receptor 1 (ESR1), steroidogenic acute regulatory protein (STAR), cytochrome P450 family 11 subfamily A member 1 (CYP11A1), cytochrome P450 family 17 subfamily A member 1 (CYP17A1), cytochrome P450 family 19 subfamily A member 1 (CYP19A1), hydroxyl-delta-5-steroid dehydrogenase 3-beta (HSD3B), and hydroxysteroid 17-beta dehydrogenase $(H S D 17 B)$. Primers were designed for the constitutively expressed mRNAs, glyceraldehyde-3-phosphate dehydrogenase (GAPDH), ribosomal protein L 15 (RPL15), and ribosomal protein $L 19$ (RPL19), with the expression value of each gene normalized to the mean values of these genes (Table 1). Relative expression values were obtained by determining the PCR amplification efficiency $(E=2)$ to the power of the delta-delta threshold cycle $(\Delta \Delta \mathrm{Ct})$ obtained from the $\Delta \mathrm{Ct}$ least square mean differences of pairwise comparisons between initial and cultured tissue (23). 
Table 1

List of genes and primers used for quantitative real-time PCR

\section{Target genes and abbreviations \\ NCBI Sequence Primer Primer Sequence}

Glyceraldehyde-3-phosphate dehydrogenase (GAPDH)

Ribosomal protein $\mathrm{L} 15$

(RPL15)

Ribosomal protein L 19

(RPL19)
NM_001034034 Forward 5'-GGCGCCAAGAGGGTCAT-3'

Reverse 5'-ACGCCCATCACAAACATGG-3'

AY786141

Forward 5'-TGGAGAGTATTGCGCCTTCTC-3'

Reverse 5'-CACAAGTTCCACCACACTATTGG$3^{\prime}$

NM_001040515 Forward 5'-

Reverse $\quad 3$

CAGACGATACCTGAATCTAAGAAGA-

5'-TGAGAATCCGCTTGTTTTTGAA-3'

Follicular stimulating hormone receptor (FSHR)

NM_174061

Forward

Reverse

5'-CGACTCTGTCACTGCTCTAACGG-

$3^{\prime}$

5 -

CGTCAATTCCTTTGGCATAGGTGG$3^{\prime}$

Luteinizing hormone/
choriogonadotropin receptor

(LHCGR)

NM_174381 Forward 5'-CAGTCCCCCGCTTTCTCAT-3'

Steroidogenic acute

regulatory protein (STAR)

XR_083945

Reverse

5'-GTAGAGCCCCATGCAGAAGTCT-3'

Forward 5'-GGATTAACCAGGTTCGGCG-3'

Reverse 5'-CTCTCCTTCTTCCAGCCCTC-3'

Cytochrome P450 family 11

subfamily A member 1

(CYP11A7)

NM_176644

Forward

Reverse

5'-GCCACATCGAGAACTTCCAGAAG$3^{\prime}$

5 -

CTGGTGTGGAACATCTTGTAGACG$3^{\prime}$

Hydroxyl-delta-5-steroid dehydrogenase 3-beta

(HSD3B)

NM_174343

Forward

5 -

TGTTGGTGGAGGAGAAGGATCTG-3'

Reverse

5 -

TGGGTACCTTTCACATTGACGTTC-3'

Hydroxysteroid 17-beta

dehydrogenase (HSD17B)

NM_001102365 Forward

5'-TTGTGCGAGAGTCTGGCGATTCT-

Reverse

5'-AGGAATCGCTCGGTGGTGAAGTA$3^{\prime}$

Cytochrome P450 family 17 subfamily A member 1 (CYP17A7)
NM_174304

Forward

5'-TGTGGCCCCTACGCTGAT-3'

Reverse
5'-CGCCAATGCTGGAGTCAAT-3' 


\begin{tabular}{|c|c|c|c|}
\hline $\begin{array}{l}\text { Target genes and } \\
\text { abbreviations }\end{array}$ & NCBI Sequence & Primer & Primer Sequence \\
\hline \multirow{3}{*}{$\begin{array}{l}\text { Cytochrome P450 family } 19 \\
\text { subfamily A member } 1 \\
\text { (CYP19A1) }\end{array}$} & \multirow[t]{3}{*}{ NM_174305 } & Forward & \multirow{2}{*}{$\begin{array}{l}5^{\prime}- \\
\text { GTCCGAAGTTGTGCCTATTGCCAGC- } \\
3^{\prime}\end{array}$} \\
\hline & & Reverse & \\
\hline & & & $\begin{array}{l}5^{\prime}- \\
\text { CCTCCAGCCTGTCCAGATGCTTGG } \\
-3^{\prime}\end{array}$ \\
\hline \multirow[t]{2}{*}{ Estrogen receptor 1 (ESR1) } & \multirow[t]{2}{*}{ NM_001001443 } & Forward & 5'-AGGGAAGCTCCTATTTGCTCC-3' \\
\hline & & Reverse & 5'-CGGTGGATGTGGTCCTTCTCT-3' \\
\hline \multirow{2}{*}{$\begin{array}{l}\text { Fibroblast growth factor } 2 \\
(F G F 2)\end{array}$} & \multirow[t]{2}{*}{ NM_174056 } & Forward & 5'-GAACGGGGGCTTCTTCCT-3' \\
\hline & & Reverse & 5'-CCCAGTTCGTTTCAGTGCC-3' \\
\hline \multirow{2}{*}{$\begin{array}{l}\text { Prostaglandin E synthase } \\
(P G E S)\end{array}$} & \multirow[t]{2}{*}{ NM_174443 } & Forward & 5'-AGGACGCTCAGAGACATGGA-3' \\
\hline & & Reverse & 5'-TTCGGTCCGAGGAAAGAGTA-3' \\
\hline \multirow{2}{*}{$\begin{array}{l}\text { Vascular endothelial growth } \\
\text { factor A isoform } 121 \\
\text { (VEGFA121) }\end{array}$} & \multirow[t]{2}{*}{ NM_174216 } & Forward & 5'- CCGTCCCATTGAGACCCTG-3' \\
\hline & & Reverse & $\begin{array}{l}\text { 5'- }^{\prime} \text { CGGCTTGTCACAATTTTTCTTGTC-3' }\end{array}$ \\
\hline
\end{tabular}

Follicle tissue lysis and RNA extraction were conducted according to the manufacturer's recommendations (PureLink RNA Mini Kit, Invitrogen, Carlsbad, CA, USA). Isolated RNA was evaluated for concentration and purity using a NanoDrop One Spectrophotometer (Thermo Fisher Scientific, Waltham, MA, USA). A maximum of $2 \mu \mathrm{g}$ of mRNA was used to synthesize complementary DNA using a commercial kit (High-capacity cDNA Reverse Transcription Kit, Applied Biosystems, Foster City, CA, USA) supplemented with RNase inhibitor (RNase Inhibitor, human placenta, New England BioLabs, Ipswich, MA, USA). Complementary DNA was used for quantitative real-time reverse transcription PCR using a 7500 Real-Time PCR Detection System (Applied Biosciences) with PowerUp ${ }^{\text {TM }}$ SYBR $^{\text {TM }}$ Green Master Mix (2X; Applied Biosciences). All assays were carried out in triplicate for each target mRNA. The amplification conditions were as follows: $50^{\circ} \mathrm{C}$ for $2 \mathrm{~min}, 95^{\circ} \mathrm{C}$ for $2 \mathrm{~min}$, and 40 cycles at $95^{\circ} \mathrm{C}$ for $15 \mathrm{~s}$ and $60^{\circ} \mathrm{C}$ for $60 \mathrm{~s}$.

\section{Statistical analyses}

Data are presented as percentage mean \pm SEM. All statistical analyses were performed using $\mathrm{R}$ Version 3.4.3 (https://www.r-project.org/). Normality was confirmed using a Shapiro-Wilk test of the residuals. Non-normal data were transformed using Tukey's Ladder of Powers. If transformation did not result in a normalized population, a Kruskal-Wallis rank-sum test was performed. Analysis of variance was applied to parametric data using a general linear mixed model with repeated measures applied for hormone data. The covariance structure that resulted in the smallest Bayesian information criterion was selected from the mixed models. Significance was declared at $P \leq 0.05$. 


\section{Results}

Progesterone production from follicular tissue (Fig. 2A) changed over time in the culture system $(P<0.01)$ but was not altered by NGF treatment $(P=0.81)$ or treatment by time interactions $(P=0.54)$. Consistently, there were no changes in gene expression of steroidogenic enzymes responsible for the conversion of cholesterol to pregnenolone (STAR, CYP11A1; P $\geq 0.34$; Table 2) or pregnenolone to progesterone (HSD3B; $P=0.60$, Fig. 2B) after treatment with NGF for $72 \mathrm{~h}$. Testosterone production in NGF-treated follicular tissue (Fig. 2C) was higher than in untreated controls $(P<0.01)$, but not affected by time $(P=0.54)$ or treatment by time interactions $(P=0.62)$. While there was no change in follicular CYP17A1 expression ( $P$ $=0.31$; Table 2$)$, whose enzyme converts progesterone to androstenedione, NGF treatment upregulated follicular HSD17B expression ( $P=0.04$; Fig. 2D), whose enzyme converts androstenedione to testosterone in the theca cells (Fortune, 1986). Testosterone produced by theca cells is typically converted to estradiol in the granulosa cell via the aromatase enzyme (CYP19A1) (21). The results of the current study found that follicular estradiol production (Fig. 2E) was unaffected by NGF treatment $(P=0.14)$, time $(P=0.60)$, or treatment by time interactions $(P=0.73)$. Consistently, follicular CYP19A1 expression was also unaffected by NGF treatment $(P=0.53$; Fig. 2 F).

Table 2

Fold change in mRNA expression of gonadotropin receptors, angiogenic enzymes, and steroidogenic enzymes in bovine follicle wall tissue preparations treated with $100 \mathrm{ng} / \mathrm{mL}$ NGF vs. untreated (Control) for $72 \mathrm{~h}$. Data is presented as mean \pm SEM.

\begin{tabular}{|llll|}
\hline Gene names and abbreviations & Control & NGF & $\begin{array}{c}\boldsymbol{P} \\
\text { value }\end{array}$ \\
\hline Steroidogenic acute regulatory protein (STAR) & $0.17 \pm 0.02$ & $0.29 \pm 0.1$ & 0.34 \\
\hline $\begin{array}{l}\text { Cytochrome P450 family 11 subfamily A member 1 } \\
\text { (CYP17A1) }\end{array}$ & $17.81 \pm 9.2$ & $8.67 \pm 5.0$ & 0.40 \\
\hline $\begin{array}{l}\text { Cytochrome P450 family 17 subfamily A member 1 } \\
\text { (CYP17A1) }\end{array}$ & $0.01 \pm 0.00$ & $0.01 \pm 0.00$ & 0.31 \\
\hline Luteinizing hormone/ choriogonadotropin receptor (LHCGR) & $0.07 \pm 0.01$ & $0.09 \pm 0.03$ & 0.41 \\
\hline Follicular stimulating hormone receptor (FSHR) & Undetected & Undetected & N/A \\
\hline Estrogen receptor alpha (ESR1) & $0.04 \pm 0.01$ & $0.05 \pm 0.02$ & 0.77 \\
\hline
\end{tabular}

The cultured tissue was derived from follicles destined to ovulate within $24 \mathrm{~h}$ based on the synchronization protocol used. Therefore, by $72 \mathrm{~h}$, we expected to see changes consistent with the postovulatory follicular to luteal transition. Following ovulation, the LH-receptor-bearing theca cells luteinize and become small luteal cells that secrete progesterone in response to $\mathrm{LH}$ signaling $(24,25)$. On the other hand, FSH-receptor-bearing granulosa cells luteinize and become large luteal cells, losing their FSH receptors (26). Follicular expression of $L H C G R$ was unaltered by treatment after $72 \mathrm{~h}$ culture $(P=0.41)$, whereas FSHR was undetectable by the assay (Table 2). Another change commonly found during this transitional period is increased expression of ESR1 during follicular growth and early luteal phase (d 1 
through 4 of the estrous cycle) (27). We found no increase in the expression of ESR1 following the 72-h culture period in either treatment group $(P=0.77$; Table 2$)$.

In cattle, ovarian function depends on a complex remodeling of the vascular system between ovulation and $C L$ development that involves the temporal expression of vascular endothelial growth factor $A$ (VEGFA) and fibroblast growth factor 2 (FGF2) (28). Another factor crucial to ovulation and CL formation is PGE, which can be stimulated from bovine theca cells with NGF treatment and is thought to be derived from PGE synthase (PGES) activity $(5,29)$. The results herein demonstrated that NGF treatment downregulated expression of FGF2 $(P=0.02$; Fig. 3A) but did not alter VEGFA121 $(\mathrm{P}=0.44$; Fig. 3B) or $P G E S(P$ $=0.63$; Fig. $3 \mathrm{C}$ ) expression in bovine follicle tissue.

\section{Discussion}

The current study evaluated the direct effects of NGF, purified from bull seminal plasma, on bovine preovulatory follicle tissue. In a previous study, androstenedione and progesterone production was increased in isolated bovine theca cells treated with recombinant NGF (5). Androstenedione is converted to testosterone in the theca cells by the enzyme hydroxysteroid 17-beta dehydrogenase (HSD17B) (21), both of which were increased in the current study. Despite the increased production of its testosterone precursor, estradiol concentrations and aromatase enzyme gene expression (CYP19A1) were unaffected by NGF treatment. Previously, the highest expression of ESR1 was observed in the theca interna cells of growing pre-ovulatory follicles in the bovine ovary and thought to provide a local feedback loop, where estradiol produced by granulosa cells could be used to further stimulate theca cell androgen production (27). The current study did not find an effect of NGF treatment of ESR1 expression in bovine follicular tissue, further suggesting that this feedback loop is not the potential signaling mechanism for NGFinduced androgen production. However, NGF stimulated proliferation of theca cells from bovine preovulatory follicles (5). Therefore, the increase in testosterone production observed herein could be due to an increase in theca cell number, since estradiol production by the granulosa cells was unaffected.

Treatment of follicle tissue with NGF did not alter the expression of other steroidogenic enzymes or progesterone production, which serves as a precursor for androstenedione production in the preovulatory follicle (21). This is not in agreement with a previous observation of increased theca cell progesterone production in response to NGF treatment (5). One difference between studies is that our culture media contained gonadotropins (LH/FSH) in both control and NGF wells, attempting to emulate the preovulatory cascade, whereas the previous study treated only the control wells with gonadotropins (5). Supplementing culture media with LH and FSH stimulated endogenous NGF secretion from medium to large follicles in ewes (8). Therefore, the inclusion of gonadotropins in the control medium, but not in the NGF-treated medium, may confound the outcomes of exogenous NGF supplementation since the ovary is capable of endogenous NGF production in response to gonadotropin signaling. It is also worth noting that human chorionic gonadotropin (hCG) was used to treat control samples previously rather than $\mathrm{LH}$ (5). While hCG shares the same receptor with LH, hCG also stimulates different intracellular signaling pathways (30), which could alter its downstream effects. 
Interestingly, there was a downregulation in gene expression of $F G F 2$ and no change in gene expression of VEGFA121 in follicle tissue treated with NGF. Both VEGFA and FGF2 promote vascular supply growth during follicular to luteal transition in the cow ovary, with resulting changes in their localization patterns $(31,32)$. Follicular FGF2 mRNA and FGF2 protein increased around $4 \mathrm{~h}$ after $\mathrm{GnRH}$ administration in cows, corresponding with the LH surge (33). Immediately following the LH surge, FGF2 stimulates the migration and proliferation of endothelial cells that help to establish luteal blood flow (28). During early CL formation, FGF2 concentrations decrease while the capillary beds are reconstructed to establish blood flow (28). In contrast, VEGFA concentrations remain high throughout ovulation and CL development to support endothelial cell survival (28). Given that the assays were performed after $72 \mathrm{~h}$ in culture, it is possible that the timing of this reconstruction phase was hastened by NGF treatment, which may account for the observed decrease in FGF2 expression. Future studies assessing the temporal expression of these angiogenic enzymes are warranted to clarify exactly how NGF could alter the follicular to luteal transition.

Previously, NGF treatment stimulated PGE release for up to $8 \mathrm{~h}$ in theca cells extracted from bovine preovulatory follicles (5). Prostaglandin $\mathrm{E}_{2}$ is synthesized by PGES and acts as a pro-angiogenic molecule in vascular endothelium by recruiting the paracrine-autocrine mechanism characteristic of endothelium cells, resulting in vascular remodeling (34). Prostaglandin $E_{2}$ also supports luteal progesterone production in cattle (35), potentially through increased CL vascularity (36). Consistently, one study observed higher PGES mRNA and PGES protein levels in the CL of early pregnancy (days 20 to 30 ) than in the luteal phase (days 8 to 12 of the estrous cycle) or after 40 days gestation of artificially inseminated cows (37). To our surprise, NGF treatment did not enhance follicular expression of $P G E S$ in the current study. However, HSD17B enzymes have also been found to play a role in the synthesis of arachidonic acid and its downstream eicosanoid metabolites, such as PGE (38). Additionally, HSD17Bknockout female mice failed to initiate pseudopregnancy after being mated by sterile males despite exhibiting normal cycles (39), suggesting a crucial role of this enzyme in CL development. Therefore, NGF may influence ovulation and CL development indirectly through its effects on ovarian HSD17B enzyme activity.

After ovulation, theca cells differentiate into small luteal cells that, in response to LH binding, produce an early rise in progesterone that is essential for supporting initial embryonic growth (40). Though we found no differences in expression of $\angle H C G R$ in the current study, it would be worthwhile to evaluate its expression in vivo to determine if there are downstream effects on the presence of small luteal cells in the mature bovine CL. This finding may explain how systemic administration of NGF can improve CL development and function in cattle $(12,14,15,41)$.

\section{Concluding Remarks}

In conclusion, the results of the current study demonstrated that purified bovine NGF could act directly on the theca and granulosa cells of the bovine pre-ovulatory follicle to stimulate testosterone production, which may be secondary to theca cell proliferation. Additionally, decreased FGF2 expression in NGF- 
treated tissue suggests hastened onset of tissue remodeling that occurs during early luteal development. Further studies are warranted to unravel the putative roles of NGF in ovulation and luteal formation in cattle.

\section{Abbreviations}

$\mathrm{CL}=$ Corpus luteum

CYP11A1 = Cytochrome P450 family 11 subfamily A member 1

CYP17A1 = Cytochrome P450 family 17 subfamily A member 1

CYP19A1 = Cytochrome P450 family 19 subfamily A member 1

ESR1 $=$ Estrogen receptor

$\mathrm{FSH}=$ Follicle stimulating hormone

GAPDH = Glyceraldehyde-3-phosphate dehydrogenase

HSD3B = Hydroxyl-delta-5-steroid dehydrogenase 3-beta

HSD17B = Hydroxysteroid 17-beta dehydrogenase

$\mathrm{LH}=$ Luteinizing hormone

LHCGR $=$ LH/choriogonadotropin receptor

NGF $=$ Nerve growth factor $-\beta$

PGE = Prostaglandin E2

PGES $=$ PGE synthase

$\mathrm{PGF}_{2 \mathrm{a}}=$ Prostaglandin $\mathrm{F}_{2 \mathrm{a}}$

RPL15 - Ribosomal protein L15

RPL19 - Ribosomal protein L19

StAR $=$ Steroidogenic acute regulatory protein

VEGFA121 = Vascular endothelial growth factor $\mathrm{A}$ isoform 121

\section{Declarations}




\section{Ethics approval}

All experimental procedures in the present study were conducted from July to August 2018 at the College of Veterinary Medicine, University of Illinois Urbana-Champaign. The Institutional Animal Care approved all the animal procedures and Use Committees of the University of Illinois at Urbana-Champaign, USA (Protocol \#18223).

\section{Consent for publication}

Not applicable.

\section{Availability of data and materials}

All data is fully present in the manuscript and any details will be made available per request.

\section{Competing interest}

The authors declare no competing interests.

\section{Funding}

This work was supported by the National Institute of Food and Agriculture at the U.S. Department of Agriculture Hatch Funds (Accession number: 1014712).

\section{Author's contribution}

JLS, JAF, IFC, and FSL contributed to conception and design of the work. JLS, IFC, and FSL contributed to sample colelction. JLS and LG contributed to culture theca and granulosa cells. VRGM and NWD contributed to hormonal assay analysis. JLS contributed to real-time PCR analysis. JLS, IFC and FSL contributed to data analysis and interpretation. JLS prepared the manauscript. All author read and contributed to final version submitted for publication.

\section{Acknowledgments}

The authors would like to thank the staff at the University of Illinois Veterinary Research Farm for assistance with obtaining heifers for use within this study. We would also like to acknowledge the invaluable input provided by Drs. Clifford Shipley, PrabhakaraReddi, and David Miller regarding the design of this study. Additionally, we thank Stephanie Stella and Laís Cunha for their assistance with animal protocols.

\section{Authors' information}

${ }^{1}$ Department of Veterinary Clinical Medicine, College of Veterinary Medicine, University of Illinois, Urbana, Illinois, USA 
${ }^{2}$ Department of Comparative Biosciences, College of Veterinary Medicine, University of Illinois, Urbana, Illinois, USA.

${ }^{3}$ Present address: Department of Large Animal Clinical Sciences, Virginia-Maryland College of Veterinary Medicine, Virginia Polytechnic Institute and State University, Blacksburg, Virginia, USA

${ }^{4}$ Department of Animal and Poultry Sciences, Virginia Polytechnic Institute and State University, Blacksburg, Virginia, USA

${ }^{5}$ Department of Population Health and Reproduction, School of Veterinary Medicine, University of California, Davis, CA, 95616, USA

\section{References}

1. Dissen GA, Hill DF, Costa ME, Les Dees CW, Lara HE, Ojeda SR. A role for trkA nerve growth factor receptors in mammalian ovulation. Endocrinology. 1996;137(1):198-209.

2. Dissen GA, Romero C, Hirshfield AN, Ojeda SR. Nerve growth factor is required for early follicular development in the mammalian ovary. Endocrinology. 2001;142(5):2078-86.

3. Dissen GA, Hirshfield AN, Malamed S, Ojeda SR. Expression of neurotrophins and their receptors in the mammalian ovary is developmentally regulated: changes at the time of folliculogenesis. Endocrinology. 1995;136(10):4681-92.

4. Ojeda SR, Romero C, Tapia V, Dissen GA. Neurotrophic and cell-cell dependent control of early follicular development. Mol Cell Endocrinol. 2000;163(1-2):67-71.

5. Dissen GA, Parrott JA, Skinner MK, Hill DF, Costa ME, Ojeda SR. Direct effects of nerve growth factor on thecal cells from antral ovarian follicles. Endocrinology. 2000;141(12):4736-50.

6. Tsafriri A, Lindner HR, Zor U, Lamprecht SA. Physiological role of prostaglandins in the induction of ovulation. Prostaglandins. 1972;2(1):1-10.

7. Mayerhofer A, Dissen GA, Parrott JA, Hill DF, Mayerhofer D, Garfield RE, et al. Involvement of nerve growth factor in the ovulatory cascade: trkA receptor activation inhibits gap junctional communication between thecal cells. Endocrinology. 1996;137(12):5662-70.

8. Mattioli M, Barboni B, Gioia L, Lucidi P. Nerve growth factor production in sheep antral follicles. Domest Anim Endocrinol. 1999;17(4):361-71.

9. Barboni B, Mattioli M, Gioia L, Turriani M, Capacchietti G, Berardinelli P, et al. Preovulatory rise of NGF in ovine follicular fluid: possible involvement in the control of oocyte maturation. Microsc Res Tech. 2002;59(6):516-21.

10. Kershaw-Young CM, Druart X, Vaughan J, Maxwell WM. beta-Nerve growth factor is a major component of alpaca seminal plasma and induces ovulation in female alpacas. Reprod Fertil Dev. 2012;24(8):1093-7. 
11. Ratto MH, Leduc YA, Valderrama XP, van Straaten KE, Delbaere LTJ, Pierson RA, et al. The nerve of ovulation-inducing factor in semen. P Natl Acad Sci USA. 2012;109(37):15042-7.

12. Stewart JLS, Cunha S, Dias L, Canisso NW, Mercadante IF, Cardoso VRG, Williams RC, Pohler GL, Lima KG. F. S. Administration of nerve growth factor-b to heifers with a pre- ovulatory follicle enhanced luteal formation and function and promoted LH release. Theriogenology. 2020;148:37-47.

13. Stewart JL, Mercadante VRG, Dias NW, Canisso IF, Yau P, Imai B, et al. Nerve Growth Factor-Beta, purified from bull seminal plasma, enhances corpus luteum formation and conceptus development in Bos taurus cows. Theriogenology. 2018;106:30-8.

14. Tanco VM, Van Steelandt MD, Ratto MH, Adams GP. Effect of purified llama ovulation-inducing factor (OIF) on ovarian function in cattle. Theriogenology. 2012;78(5):1030-9.

15. Tribulo P, Bogle O, Mapletoft RJ, Adams GP. Bioactivity of ovulation inducing factor (or nerve growth factor) in bovine seminal plasma and its effects on ovarian function in cattle. Theriogenology. 2015;83(9):1394-401.

16. Berland MA, Ulloa-Leal C, Barria M, Wright H, Dissen GA, Silva ME, et al. Seminal Plasma Induces Ovulation in Llamas in the Absence of a Copulatory Stimulus: Role of Nerve Growth Factor as an Ovulation-Inducing Factor. Endocrinology. 2016;157(8):3224-32.

17. Stewart JL, Canisso IF, Ellerbrock RE, Mercadante VRG, Lima FS. Nerve Growth Factor-beta production in the bull: Gene expression, immunolocalization, seminal plasma constitution, and association with sire conception rates. Animal Reproduction Science. 2018;197:335-42.

18. Knickerbocker JJ, Thatcher WW, Foster DB, Wolfenson D, Bartol FF, Caton D. Uterine prostaglandin and blood flow responses to estradiol-17 beta in cyclic cattle. Prostaglandins. 1986;31(4):757-76.

19. Krzymowski T, Stefanczyk-Krzymowska S, Koziorowski M. Counter current transfer of PGF2 alpha in the mesometrial vessels as a mechanism for prevention of luteal regression in early pregnancy. Acta Physiol Pol. 1989;40(1):23-34.

20. Schjenken JE, Robertson SA. Seminal Fluid and Immune Adaptation for Pregnancy - Comparative Biology in Mammalian Species. Reprod Domest Anim. 2014;49:27-36.

21. Fortune JE. Bovine Theca and Granulosa-Cells Interact to Promote Androgen Production. Biol Reprod. 1986;35(2):292-9.

22. Komar CM, Berndtson AK, Evans ACO, Fortune JE. Decline in circulating estradiol during the periovulatory period is correlated with decreases in estradiol and androgen, and in messenger RNA for P450 aromatase and P450 17 alpha-hydroxylase, in bovine preovulatory follicles. Biol Reprod. 2001;64(6):1797-805.

23. Livak KJ, Schmittgen TD. Analysis of relative gene expression data using real-time quantitative PCR and the 2(-Delta Delta C(T)) Method. Methods. 2001;25(4):402-8.

24. Mamluk R, Chen D, Greber Y, Davis JS, Meidan R. Characterization of messenger ribonucleic acid expression for prostaglandin F2 alpha and luteinizing hormone receptors in various bovine luteal cell types. Biol Reprod. 1998;58(3):849-56. 
25. Mamluk R, Wolfenson D, Meidan R. LH receptor mRNA and cytochrome P450 side-chain cleavage expression in bovine theca and granulosa cells luteinized by LH or forskolin. Domest Anim Endocrinol. 1998;15(2):103-14.

26. Rajapaksha WR, Robertson L, O'Shaughnessy PJ. Expression of follicle-stimulating hormone-receptor mRNA alternate transcripts in bovine granulosa cells during luteinization in vivo and in vitro. Mol Cell Endocrinol. 1996;120(1):25-30.

27. Berisha B, Pfaffl MW, Schams D. Expression of estrogen and progesterone receptors in the bovine ovary during estrous cycle and pregnancy. Endocrine. 2002;17(3):207-14.

28. Robinson RS, Woad KJ, Hammond AJ, Laird M, Hunter MG, Mann GE. Angiogenesis and vascular function in the ovary. Reproduction. 2009;138(6):869-81.

29. Nuttinck F, Marquant-Le Guienne B, Clement L, Reinaud P, Charpigny G, Grimard B. Expression of genes involved in prostaglandin E2 and progesterone production in bovine cumulus-oocyte complexes during in vitro maturation and fertilization. Reproduction. 2008;135(5):593-603.

30. Casarini L, Lispi M, Longobardi S, Milosa F, La Marca A, Tagliasacchi D, et al. LH and hCG action on the same receptor results in quantitatively and qualitatively different intracellular signalling. PLoS One. 2012;7(10):e46682.

31. Laird M, Woad KJ, Hunter MG, Mann GE, Robinson RS. Fibroblast growth factor 2 induces the precocious development of endothelial cell networks in bovine luteinising follicular cells. Reprod Fertil Dev. 2013;25(2):372-86.

32. Tamanini C, De Ambrogi M. Angiogenesis in developing follicle and corpus luteum. Reprod Domest Anim. 2004;39(4):206-16.

33. Berisha B, Steffl M, Amselgruber W, Schams D. Changes in fibroblast growth factor 2 and its receptors in bovine follicles before and after $\mathrm{GnRH}$ application and after ovulation. Reproduction. 2006;131(2):319-29.

34. Finetti F, Solito R, Morbidelli L, Giachetti A, Ziche M, Donnini S. Prostaglandin E-2 regulates angiogenesis via activation of fibroblast growth factor receptor-1. J Biol Chem. 2008;283(4):213946.

35. Miyamoto A, von Lutzow H, Schams D. Acute actions of prostaglandin F2 alpha, E2, and I2 in microdialyzed bovine corpus luteum in vitro. Biol Reprod. 1993;49(2):423-30.

36. Herzog K, Brockhan-Ludemann M, Kaske M, Beindorff N, Paul V, Niemann H, et al. Luteal blood flow is a more appropriate indicator for luteal function during the bovine estrous cycle than luteal size. Theriogenology. 2010;73(5):691-7.

37. Sakumoto R, Hayashi KG, Takahashi T. Different expression of PGE synthase, PGF receptor, TNF, Fas and oxytocin in the bovine corpus luteum of the estrous cycle and pregnancy. Reprod Biol. 2014;14(2):115-21.

38. Kemilainen H, Adam M, Maki-Jouppila J, Damdimopoulou P, Damdimopoulos AE, Kere J, et al. The Hydroxysteroid (17beta) Dehydrogenase Family Gene HSD17B12 Is Involved in the Prostaglandin 
Synthesis Pathway, the Ovarian Function, and Regulation of Fertility. Endocrinology. 2016;157(10):3719-30.

39. Hakkarainen J, Jokela H, Pakarinen P, Heikela H, Katkanaho L, Vandenput L, et al. Hydroxysteroid (17beta)-dehydrogenase 1-deficient female mice present with normal puberty onset but are severely subfertile due to a defect in luteinization and progesterone production. FASEB J. 2015;29(9):380616.

40. Harrison LM, Kenny N, Niswender GD. Progesterone Production. Lh Receptors, and Oxytocin Secretion by Ovine Luteal Cell-Types on Day-6, Day-10 and Day-15 of the Estrous-Cycle and Day-25 of Pregnancy. J Reprod Fertil. 1987;79(2):539-48.

41. Stewart JL, Canisso IF, Podicoa G, Kaplan C, Garrett EF, Shike DW, et al. Nerve growth factor-beta effects on post-thaw bull semen quality: Effects of nerve growth factor-beta added to extenders for cryopreservation of electro-ejaculated and epididymal bull semen. Animal Reproduction Science. 2019;207:107-17.

\section{Figures}

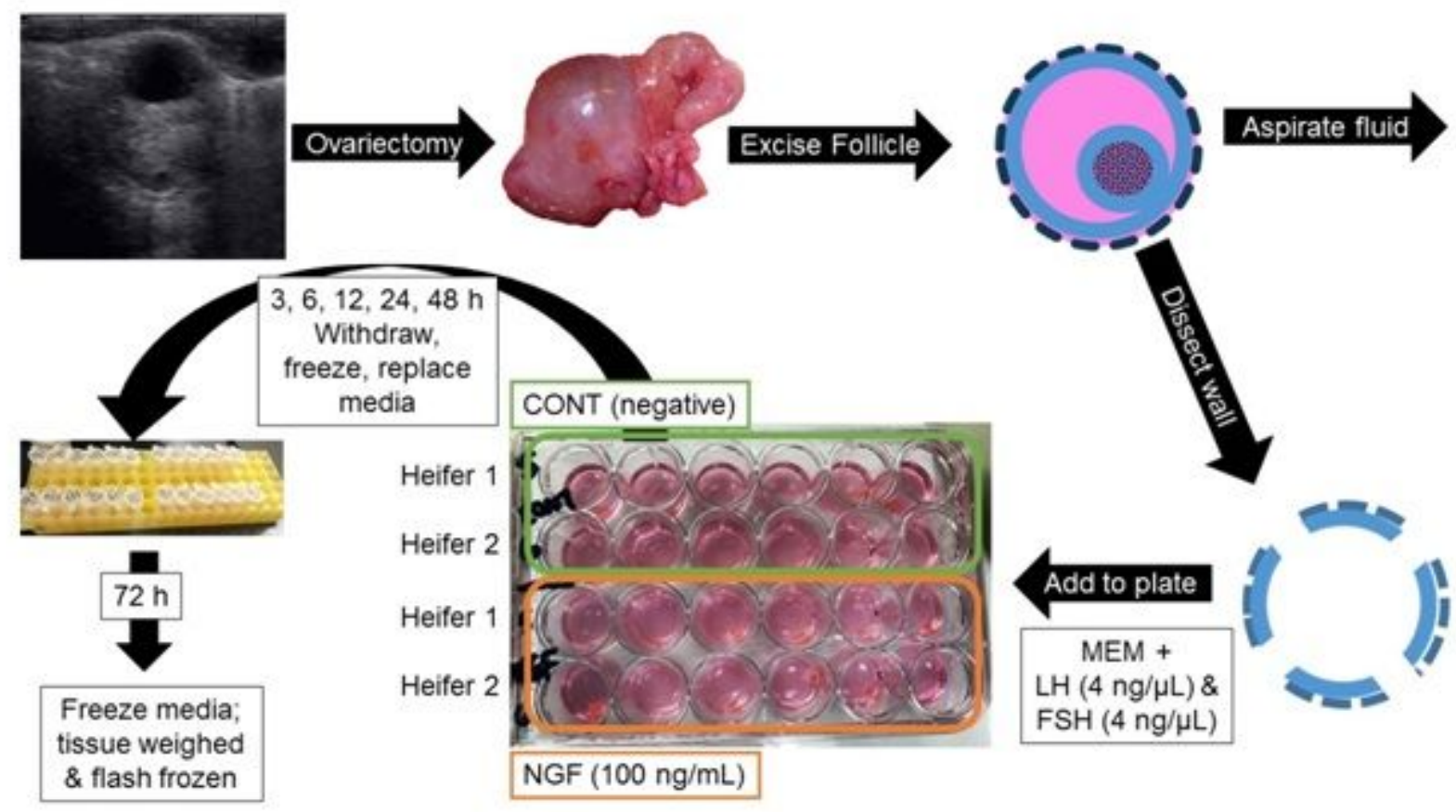

\section{Figure 1}

Graphical depiction of the methodology used to assess the effects of NGF, purified from bull seminal plasma, on the bovine pre-ovulatory follicle. 
(A)

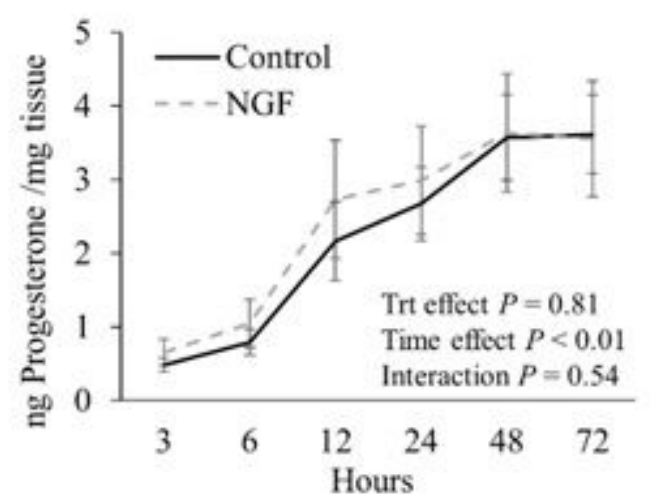

(C)

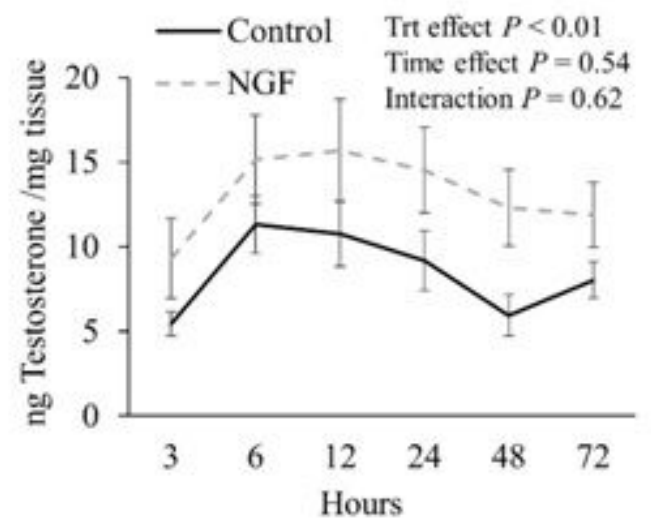

(E)

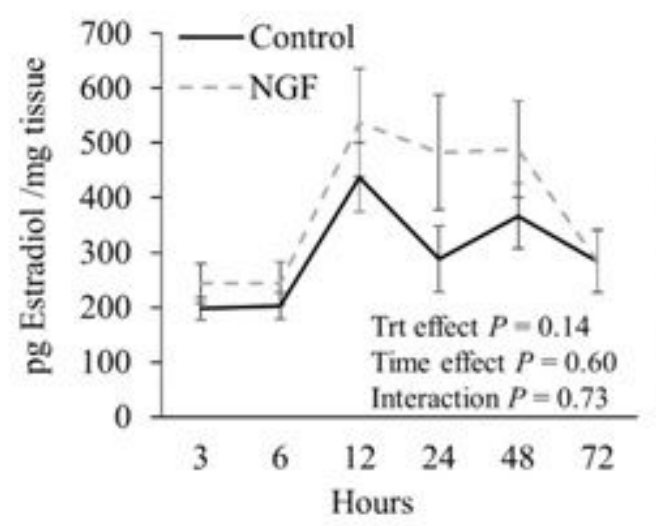

(B)

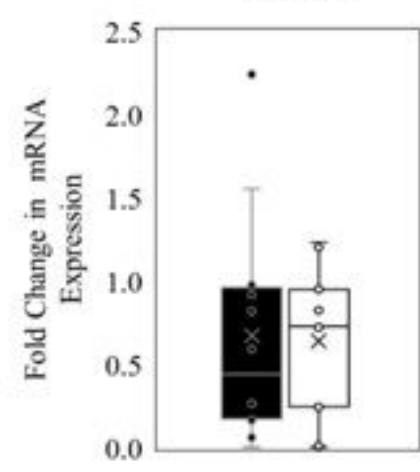

Control

$\square \mathrm{NGF}$

(D)

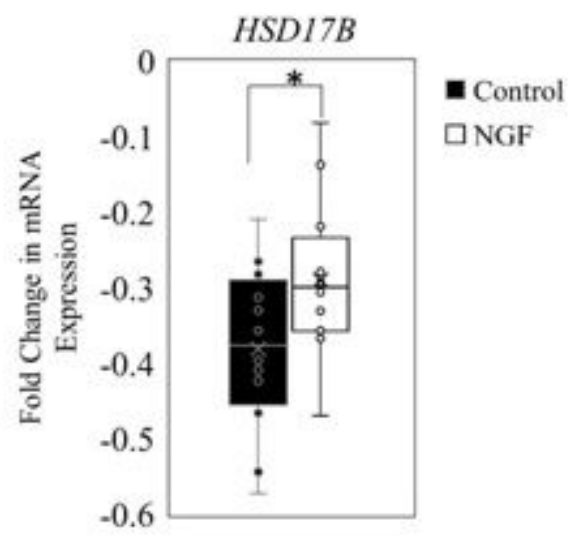

(F)

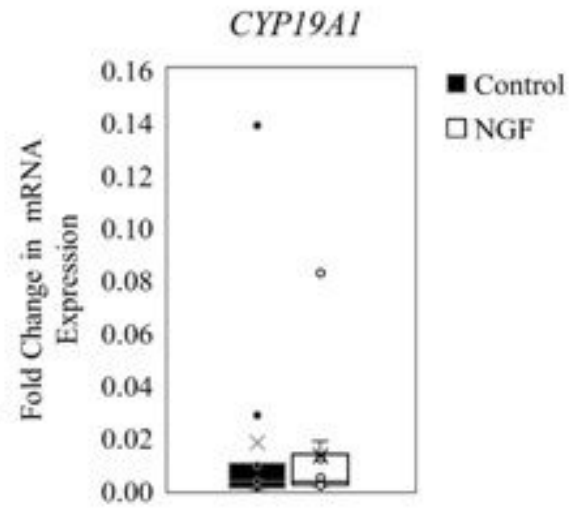

Figure 2

Steroid hormone production ( $A, C, E)$ and steroidogenic enzyme gene expression (B, D, F) in follicle tissue untreated (control) or treated with $100 \mathrm{ng} / \mathrm{mL}$ NGF for $72 \mathrm{~h}$. Hormones are presented as mean $\pm \mathrm{SEM}$, whereas genes are presented as box-and-whisker plots. * $P \leq 0.05$. 

(A)
FGF2

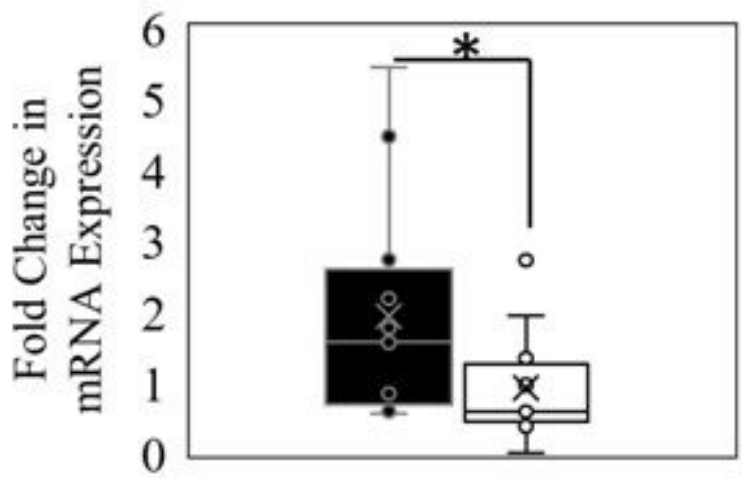

- Control

$\square \mathrm{NGF}$

(B)

VEGFA

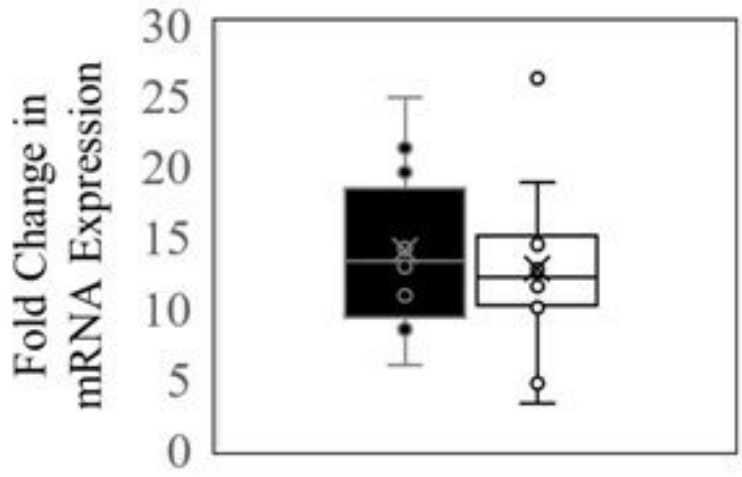

- Control

NGF

PGES

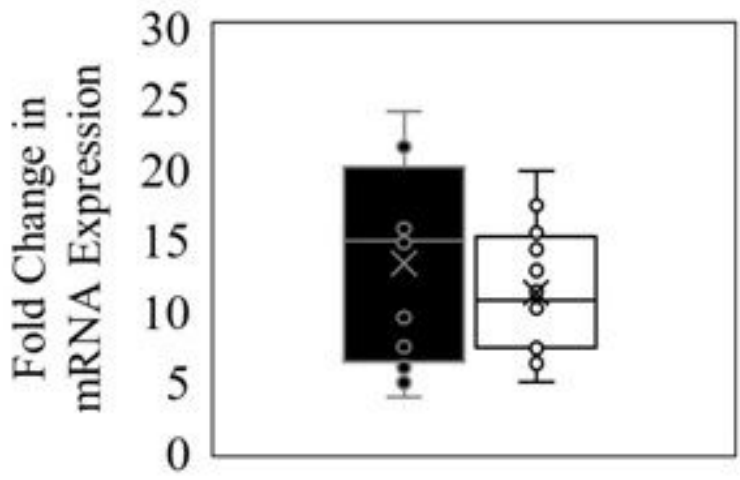

- Control

NGF

Figure 3

Box-and-whisker plots demonstrating gene expression of angiogenic enzymes in follicle tissue untreated (control) or treated with $100 \mathrm{ng} / \mathrm{mL}$ NGF for 72 h. ${ }^{*} \mathrm{P} \leq 0.05$. 